\title{
製龬工場における品質管理及びその效果 \\ 栗山俊治*・鉿木 武* \\ STATISTICAL QUALITY CONTROL AND ITS EFFECTS AT OPEN HEARTH SHOP
}

\section{Shunji Kuriyama and Takeshi Suzuki}

Since introduction of the statistical quality control into the Tsurumi Iron works, Nippon steel Tube Co. one and a half year had elapsed. In this report the authors make a brief survey of the past experience, especially with reference to the stage of introduction period.

Although many control charts had been actually used, most of them were what they call "analysing." Such was very natural in view of the present condition of our open bearth furnace engineering. Nevertheless, some good results were obtained such as the improvement of techniques and the saving of production cost.

In order to make the use of control charts more effective, it wae imperative that there should be established more complete operation standard as quickly as possible. The major effort should thus be directed to the attainment of-such aim.

\section{I. 緒言}

かが國践銅業界に品質管理が導入されてから，まだ 2,3 年經過したに過ぎない. 20 数年の歷史を持つてい

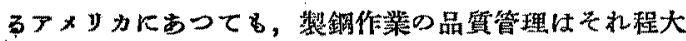
きな進步は示していないよラに見える。しかしながら， 科學的な管理の姴萧は製銓作業に關してる同じく强調さ るべきですり，純計的品質管理が，根本思想に扎いて有 力な武器であることはい5までるないところである。

私澾が品啠管理を始めてからわずかに1年牛でする

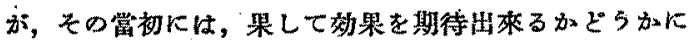

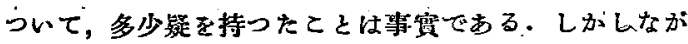
ら時の䋚つにつれて，ての疑が段々を5すらいで來た。 そして新しい管理が是非必要であるこる，又ゃらなけれ 代ならないこと，やれば必ず效果があるとい5上5なこ とがはつきりとして來た。こらした目榜を得ただけです 大き䍩檴であると思う。

\section{II. 品椞管理の离入及び經過}

鹤見製鐵所の品質管理は，昭和 26 年4月品質管理委

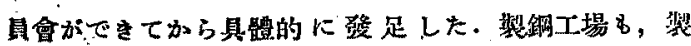

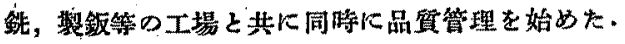

最初數人の聺貝がアメリカ規格「Z-1」及び简單な理

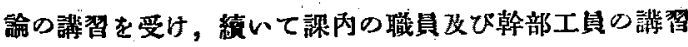
を行っだ先づ管理圆を普及するために，6 月頃より段

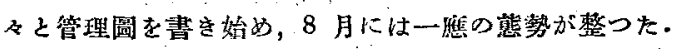

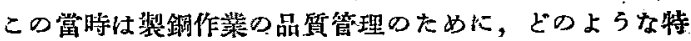
性值を選んで管理圆にすべか，文その管理圆はどのよ らな方式で書くな゙等については確信がかつたの

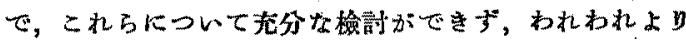
秋 1 表 炤和 26 年現在作成していた管理噣

\begin{tabular}{|c|c|c|c|c|c|}
\hline 蘩 & 管理圆項目 & \begin{tabular}{ll|} 
管 & 理 圖 \\
種 & 類
\end{tabular} & 㕌別法 & 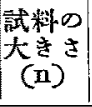 & $\begin{array}{l}\text { 管理圖. } \\
\text { 作成者 }\end{array}$ \\
\hline 料 & 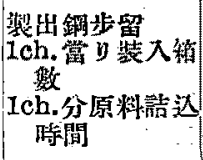 & $\begin{array}{l}x \\
x \\
x\end{array}$ & 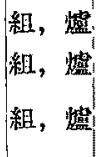 & $\begin{array}{l}1 \\
1 \\
1\end{array}$ & 原料現嚗 \\
\hline 恶 & 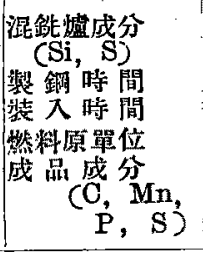 & $\begin{array}{l}X, \bar{X}-R \\
X, \bar{X}-R \\
X, \bar{X}-R \\
X, \bar{X}-R\end{array}$ & 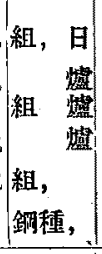 & $\begin{array}{ll}1,3 \\
1 \\
1 \\
1,4 \\
1,4\end{array}$ & 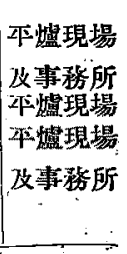 \\
\hline 塊 & 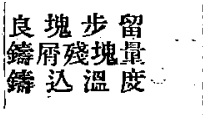 & $\begin{array}{l}x \\
x\end{array}$ & $\begin{array}{l}\text { 組 } \\
\text { 組 } \\
\text { 組 }\end{array}$ & $\begin{array}{l}1 \\
1 \\
1\end{array}$ & 造塊現場 \\
\hline $\begin{array}{l}\text { 登 } \\
\text { 生 } \\
\text { 烸篮 }\end{array}$ & 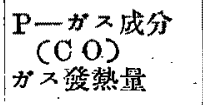 & $\begin{array}{ll}\mathrm{x}, & \mathrm{X}-\mathrm{R} \\
\mathrm{x}, & \overline{\mathrm{x}}-\mathrm{R}\end{array}$ & 組， & $\begin{array}{l}1,8 \\
1,3\end{array}$ & 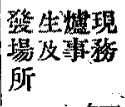 \\
\hline
\end{tabular}

* 日本銅管株式會社鹤見製鐵所 


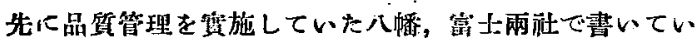

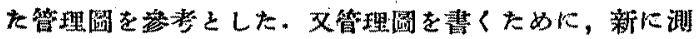
定記錄を搖すことなく，從來からとられているデーター

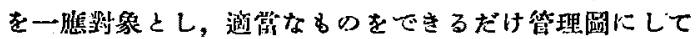
見ることにした。

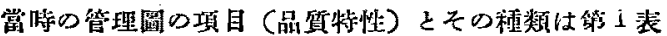
の如くである。

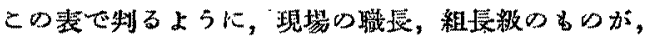
かなりの林数を白分で書いている。この理由は品質管理 を現場作業に早く取り入れるためであつた。このため， 職長，組長汃自分の日↔の作業狀態を上く把提し，自分 の仕事を反省改自して行く上にかなり役に立つたように

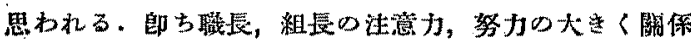
しているような项目については，段々と効果为舉つて來 たよらに思われる。

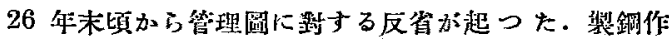
業を登理するために，修正處置が管理圆から正碓にとら

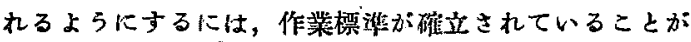

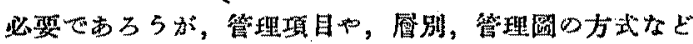
が根本的に检討されなり机ばならない。これには，熋銅

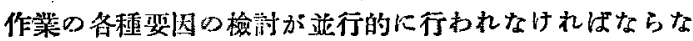

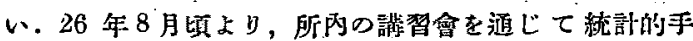

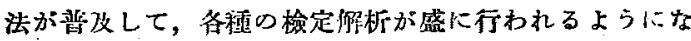

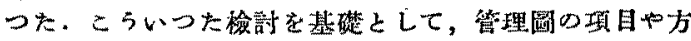
式は少しづ」變つていつた。この一環として，27 年1

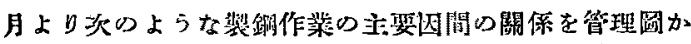
ら解析するために，嘘別に天井一代どとに， $\mathrm{n}=4$ ( ヤーデつの管理圆を 1 枚の用紅に㫫ざて書き出した。

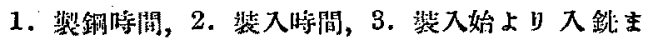

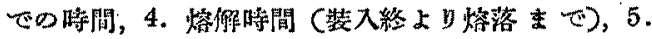

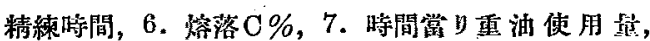

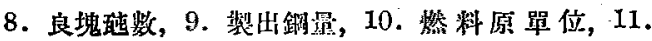
T/hr.

27.年 3 月，品質管理委貝會が，㹱来作業現場のみで

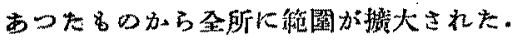

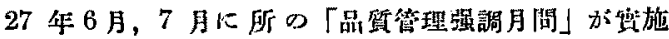

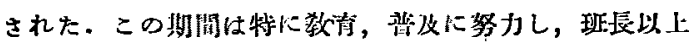
の工貝層に至るまで，品貎管理の意義，考元为，管理圆

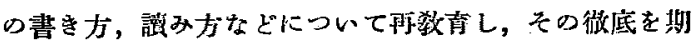
した.

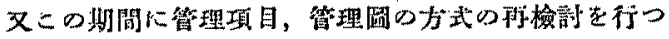
た。現在作成中心貝理泪は第 2 表の如くである。

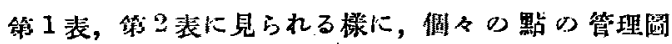
(X一管理圆) ガ多い.
鴙 2 表 现在作成している管理圆

\begin{tabular}{|c|c|c|c|c|c|}
\hline 相 & 智理圆至目 & $\begin{array}{l}\text { 徨理圆 } \\
\text { 種 数 }\end{array}$ & 跑法 & $\mid \begin{array}{l}\text { 料o } \\
\text { 大 } \\
\text { (n) }\end{array}$ & $\begin{array}{l}\text { 程理践 } \\
\text { 作成者 }\end{array}$ \\
\hline 原 & 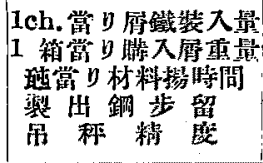 & $\begin{array}{l}\mathbf{X} \\
\mathbf{x} \\
\mathbf{X} \\
\mathbf{x}\end{array}$ & 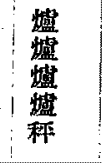 & $\begin{array}{l}1 \\
1 \\
1 \\
1 \\
1\end{array}$ & 原料現場 \\
\hline - & 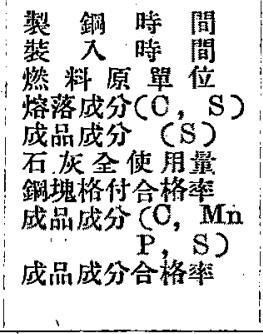 & 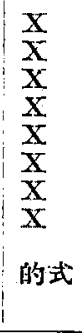 & 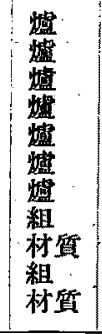 & $\begin{array}{l}1 \\
1 \\
1 \\
1 \\
1 \\
1 \\
1 \\
1 \\
1\end{array}$ & 位爐現場 \\
\hline $\begin{array}{l}\text { 造 } \\
\text { 塊 }\end{array}$ & 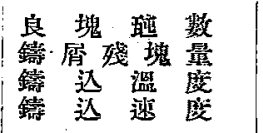 & $\begin{array}{l}\frac{X}{X} \\
X \\
X\end{array}$ & $\begin{array}{l}\text { 組 } \\
\text { 組 } \\
\text { 組犁 } \\
\text { 組型 }\end{array}$ & $\begin{array}{l}1 \\
1 \\
1 \\
1\end{array}$ & 造塊現場 \\
\hline 邆 & 装 入㫢 周 & $x$ & |組，堵 $\mid$ & 1 & 運轉現場 \\
\hline 苦 & 焙，焅 時 闻 & $x$ & 爐 & 1 & 诺灰現境 \\
\hline 所" & 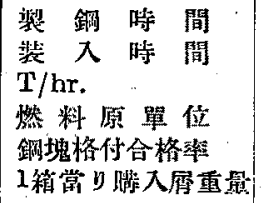 & $\frac{\frac{\bar{X}}{\bar{X}}}{\frac{\bar{X}}{\bar{X}}}$ & 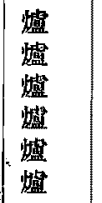 & $\begin{array}{l}4 \\
4 \\
4 \\
4 \\
4 \\
4\end{array}$ & 事称所 \\
\hline
\end{tabular}

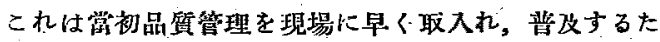
か職長，組長級に自分で書か女るために，初めから爻一

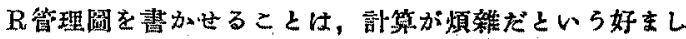
くない先入感を抱がせる惧れがあつたためである。然し その後をX一管理圆を中止していない。

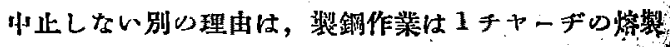
にかなりの洔閒を㢺するので，何チャーヂかの本均をと つて $\overline{\mathrm{X}}$ - Rチャーギにしたのでは, 時閒的に意味をなき なくなることと, 难的值にしためでは，各值の責任が心 ッキリしなくなるためである，又裂銅作策では，平均值

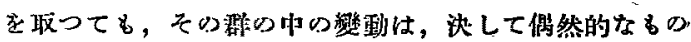

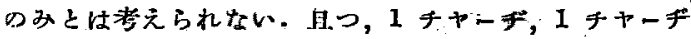
について充分注意を排つてあり，欢うなるととが可能

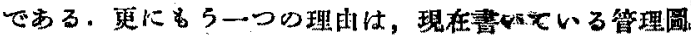

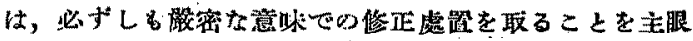
としているわけではく，いろいろな姴因把握の手段と

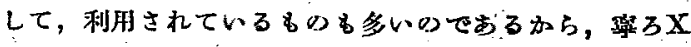
一管理圆を有利を考えている。 


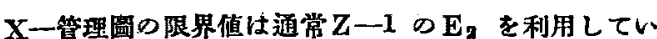
るが，特に正规型と非敌に晎なるよ5な項目について は，ヒストグラムから計算したり，或は 25 點位に小さ

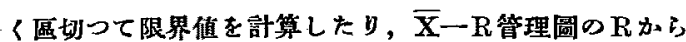
標染偏差を推定したりする. 又, 第 2 種誤差が本來問題 になつて來るが，關連する管理圆を煦するとをによ

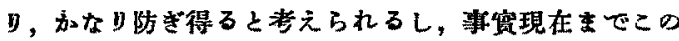
よらな證りねないらである。

他課々直接關連する問題は，26 年11月よりモデル 工場品筫管理特別分科會で製鈑工場を中心に製銅，检査 が協力して作澲，品質，步留の向上に努力して來た。

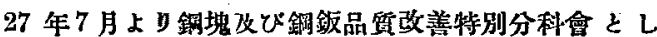

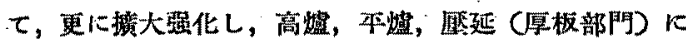

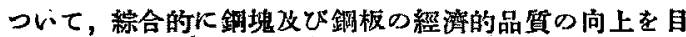

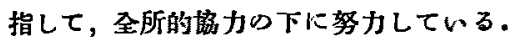

\section{III. 統計的榆定法，解析法の利用}

前述の如く，常課ひ職貝は 26 年 8 月以降，所内外D

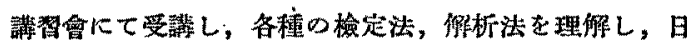
常データーの解析等に利用している．現在までかなりの 數になつているが，最も多く使用されているるのは相閶 分析法である。

以下解析を行つた 2，3の例を擧げてみると次の如く - 3 .

(1) 原 料 關 保

製銅作業におりる原料の管理は

(1) 装入時間をできるだけ短かくすること・

(2) 装入量を正確にして，ホーバーチャーヂを防 くこを.

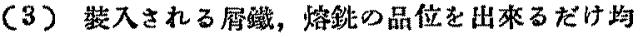
一にすること。

の3點を目的として，管理圆を書いているが，設佂その 他の關保でなかなか十分な管理ができない，前逃の如く 當課では，製出鐇步留の管理圆を書いているが，乙の變

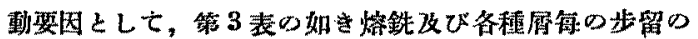
推定值を求的た。

第 3 表 揢銥及各種屑の步留推定値

\begin{tabular}{|c|c|c|c|c|c|}
\hline . & 1 緅屑 & 2 級屡 & 熔 銓 & $\begin{array}{l}1 \\
\text { プレス }\end{array}$ & $\begin{array}{l}2 \text { 級 } \\
フ^{\prime} レ \text { }\end{array}$ \\
\hline 步，留 & $95 \cdot 5 \%$ & $91 \cdot 6 \%$ & $86.2 \%$ & $79 \cdot 2 \%$ & $70 \cdot 1 \%$ \\
\hline
\end{tabular}

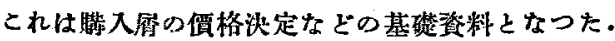

(2)平烺作業關你

(a) 平嘘作業では各種能率の僻析に，統計的な教元方
が利用されている。例えは，嘘を改造した場合，從來は 製銅時間，燃料原單位なビについて，單に不均值のみて 改造の效果等を諭じていたが，これ等の值が，天并その 他蠦皘の損粍程度に上り戀化することが分つているの で，天井一代どとに，天井包數によるこ机ら特性值の傾 向線を求めて，こ秃にりり改造の良否の制定を下してい

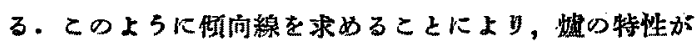
はつきり出て來て，夾の改浩方針を決める上に火切な基 礎となつている。

一例を舉げると，常所第 5 號平熷は27年 1 月，P一か

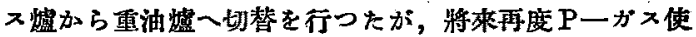
用一の切替えを考えて一部改造に止めた。次で 27 年 5

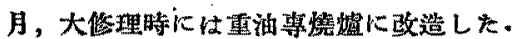

この兩時斯の成続の比較は第 4 表の虾くである．との h は, 4 チャーF゙の平均で】點を打つている トのサンブルナンバーである.

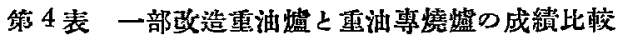

\begin{tabular}{|c|c|c|c|c|c|c|}
\hline & 期 問 & 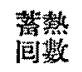 & 製鈎特間 & $\begin{array}{l}\text { 㮡料原 } \\
\text { 單 位 }\end{array}$ & $\mathrm{h}$ & 储 洘 \\
\hline 므므. & $\sim$ & $7 \sim 276$ & $\left|\begin{array}{c}6^{\circ} 57^{\prime}+ \\
2 \cdot 08^{\prime} h\end{array}\right|$ & $\left|\begin{array}{r}155 \cdot 6^{2}+ \\
1 \cdot 28^{i} h\end{array}\right|$ & $\left|\begin{array}{r}-16 \sim \\
+16\end{array}\right|$ & 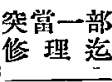 \\
\hline & $\begin{array}{r}27 \cdot 6 \cdot 1 \\
\sim 7 \cdot 2\end{array}$ & 2116 & $6^{\circ} 07^{\prime}+$ & $\left\{\begin{array}{r}128 \cdot 0^{l}+ \\
0.81^{l} \mathrm{~h}\end{array}\right.$ & $\begin{array}{r}-14-14 \\
+14\end{array}$ & \\
\hline
\end{tabular}

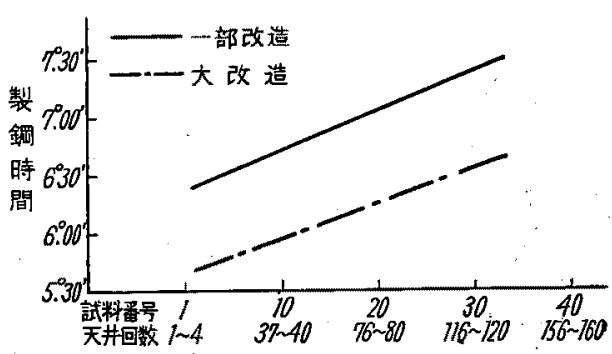

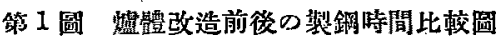

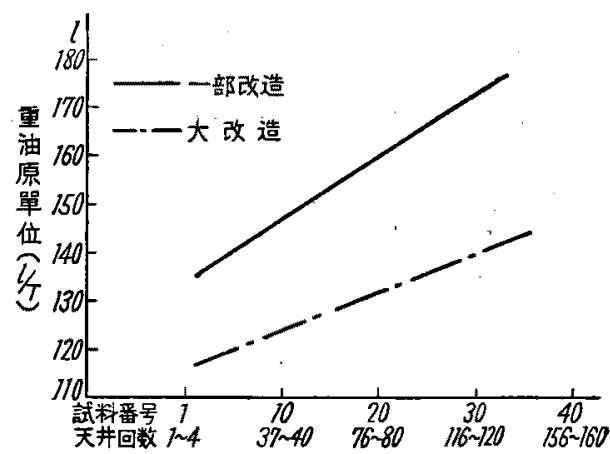

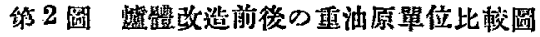


これを圖示したものが第 1,2 图らある。

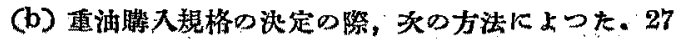

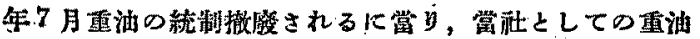
の䁖入規格を渗定する必要が起つたので，重油の性狀と 製鍓作業との關策をいるいる統計的解析を行つて調查 し，乙の結果を基礎として；他事詓所の要求條件を調整

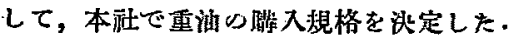

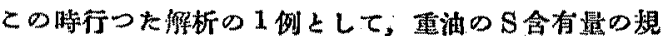

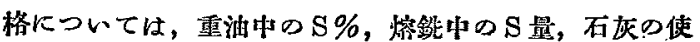

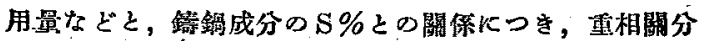
析を行つた．この結果は第 5 表及で第 3 圆の如くであ

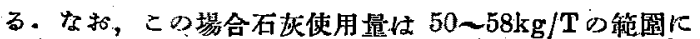
あるので一定と清えた：

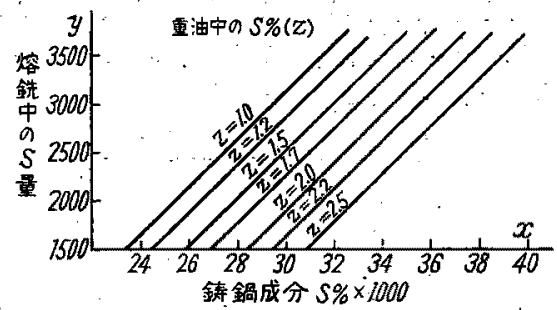

第 3 圆 重油中のS\%，聺飳中心S量之 锖鏢成分との關保

第 5 表 重相關分析表

\begin{tabular}{|c|c|c|c|}
\hline & $\cdot$ & 偨 数 & 有湆水洀 \\
\hline $\begin{array}{l}\text { 重 } \\
\text { 相 } \\
\text { 關 }\end{array}$ & 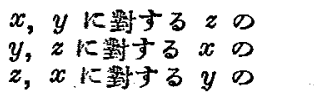 & $\begin{array}{l}0 \cdot 395 \\
0 \cdot 469 \\
0 \cdot 417\end{array}$ & $\begin{array}{l}1 \% \\
1 \% \\
1 \%\end{array}$ \\
\hline $\begin{array}{l}\text { 偏 } \\
\text { 想 } \\
\text { 關 }\end{array}$ & $\begin{array}{l}z \text { を固定した時, } x y \text { の } \\
x \text { を固定した時, } y z \text { } \\
y \text { を固定した時, } z x \text { の }\end{array}$ & $\begin{array}{l}0 \cdot 300 \\
0 \cdot 166 \\
0 \cdot 285\end{array}$ & $\begin{array}{l}1 \% \\
5 \% \\
1 \%\end{array}$ \\
\hline
\end{tabular}

$x:$ 鎝鍋成分 $\mathrm{S} \%(\times 100)$

$y$ ：熔鉄中のS 量 (熔鉄配合率 $\times$ 揢鉄中の $\mathrm{S}$ 量)

$$
(35 \sim 50 \% \times 50 \sim 80)
$$

$z$ ：重油中心S \%(1.0\%-2.5\%)

回避式俚， $x=0 \cdot 004 y+5 \cdot 02 z+12 \cdot 37$

上なり，重油中のS\%は 1.70\% 以下を䁖入規格上する こととなった.

\section{IV. 品質管理によつて得た効果}

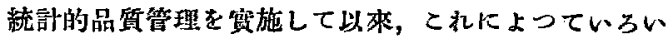
ろの點で，改盖されて來た所が多いてのことは統計的 檢定法，整析法及び管理圆を通じて，一般的に，技術的 洘元方に統計的考え方が加えられ，作業そのるのが第 に安定する方向に向っていることが、いるいるの勃果と
なつて現われるのてあつて，單純に一つの方法め2反上

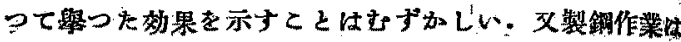

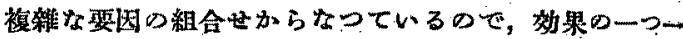
つを全て数字的に表現するととるむずかしい。

この點から，その勃果を舉げて見ると：

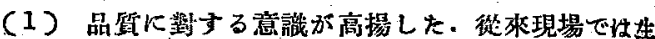

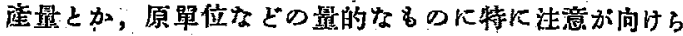

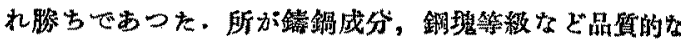
ものを管理圖等に上り，はつきり制るよらに表示したの で，品質に跱する關心が非常に高をつて來た。

例えば，䥂鍋成分分析值については，第 4 圆に見られ る如く非常に良い管理狀態を示している. 又從つて，第

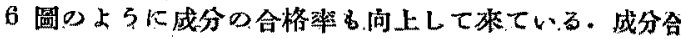
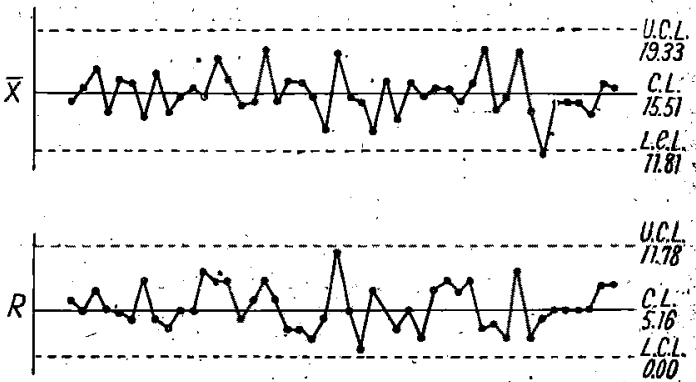

第 4 圆 鋳鋼成分 $(\mathrm{C} \% \times 100)$ 管理圆の一例

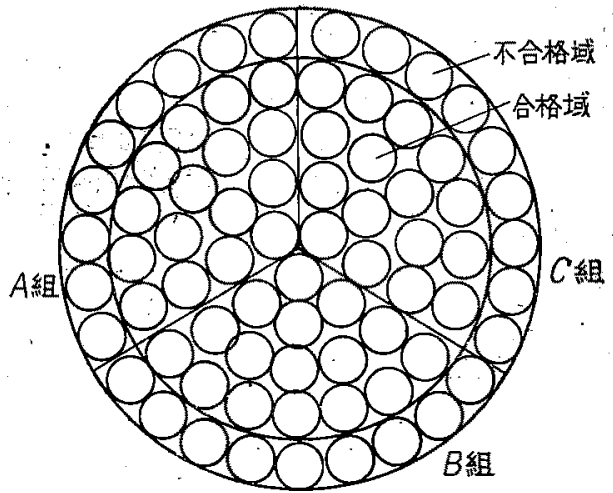

箱 5 圆的式管理圆（成品成分）

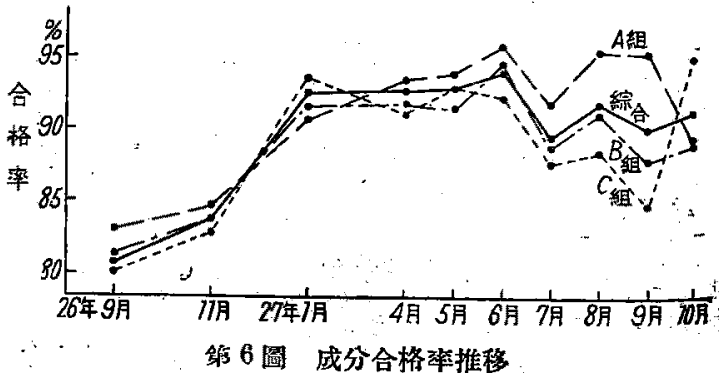


格來を高めるために，第5 圖のよ5な的式チャートは極 めて有奻であつた。

(2) データーの意昧を理解し，乙れを旮分煘重する 上らになり，現場のデーターの信赖性が高くなつた。例

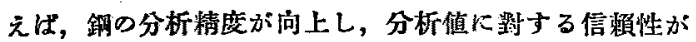

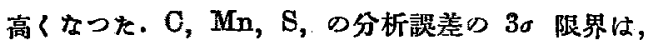
C: $\pm 0.008 \%, \mathrm{Mn}: \pm 0.02 \%, \mathrm{~S}: \pm 0.001 \%$ となつており，綪度は良い。とれに赫するサンブリング

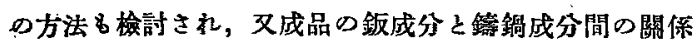
る明らかになつて來ている。

及平嘘心出䥊步留向上心點から，裝入量を均一にする ために，原料現埸に於て，每值作業萠に科量の管理を行

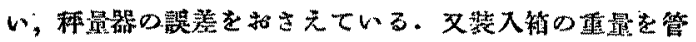

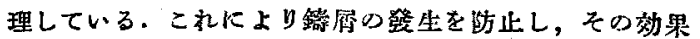

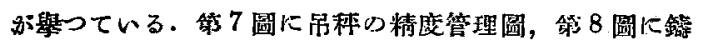
屑登生率を示しているる.

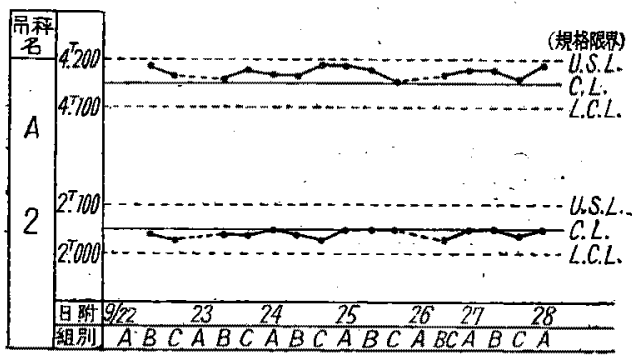

管 7 圆 吊秤精度圆

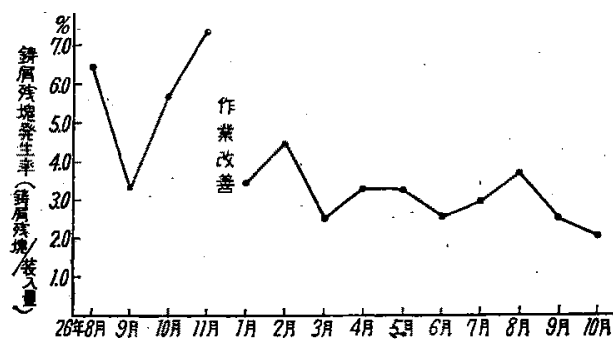

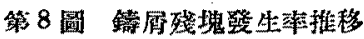

又從來迄の日誌に記錄していたデーターを，圆にして 表わし，日誌にかえて揭示し，全貝がこれに菁目するよ らになつた。

（3）品質特性の變動に数する考え方が理僻され，第 1 種の過誤の澺昹が理做されて來た。これは操業に政す

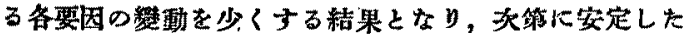
操業に向つている.

例えぼ第 9 圆の重油原單位の月别の限界線の推移に見 られる如く，夷筙に安定して來ている。これる單に管理

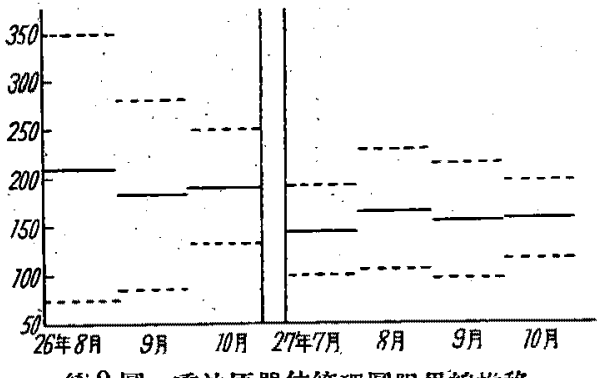

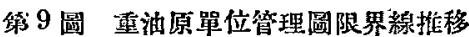

圆を書いているためといらょり，管理圆を書くことによ

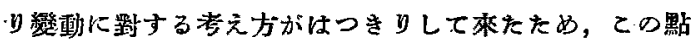
からいるいるの改善が技術的に行われて來た絴果である 之奉艺られる。

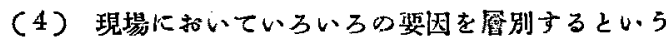

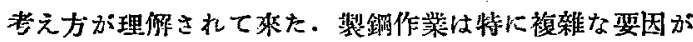

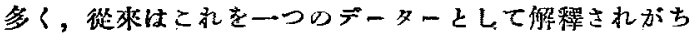
であつたが，これ㲊別して獬釋する宩え方が行われる 上らになつた。これに上り可避，不可避原因などの區別 が明らかになつ大来た。

可例えば造塊の注入速度は，從來下注ぎでは出來るだけ

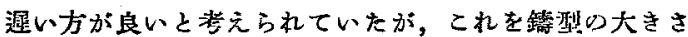

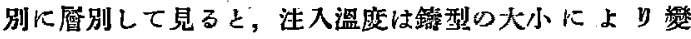
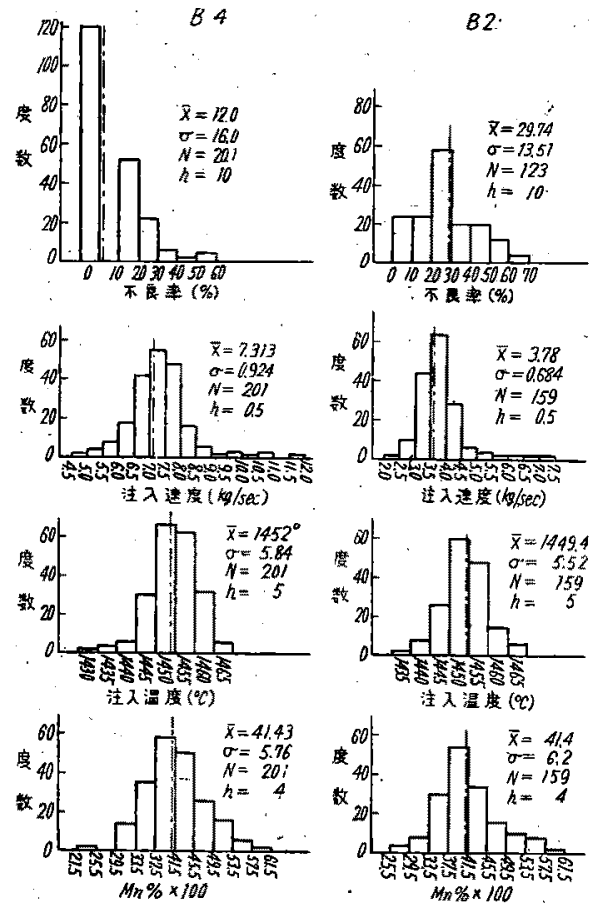

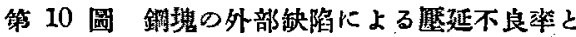
注入速度等のヒストグラム 
リ，又同一の型では注入速䏯の影響は大きくないことが 分り，原因がはつきり分るよ5になつた。（解 10 圆）

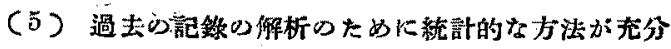
役立てられ、これによって信賴临の高いいるいろの計

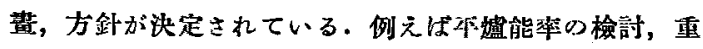

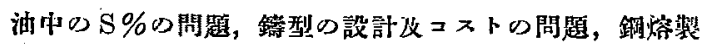
に關する諸要因の檢訪などにこの效果を舉げている。

\section{V. 管理方式に對する考察}

當工埸の品質管理は前述の如くで，まだ充分な成果を 藇げ得たとはいえないるのがある。作業としてい品澌管 理は管理圖中心で行くびものであろらが，現在の製銅 作業の㭊態からすれば，いるいるの理由で管理圆を修正

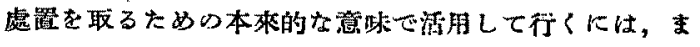
だ困難な點が多い。

製制作業では現狀に於ては，複雜な姴因を一つ一つに 分解して考えることが困難であることが多い，現在まで 書いて承夫管理圆は, 綜合的な, 或いは結果的なっのが

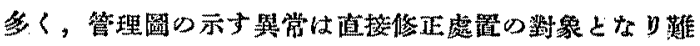
い. 又各要团間心關保がはつきりを定量的に調整できる よラになつてないるのが多かつたり, 重綮な要因で測定 法が洔間的に，精度的に不充分なものが多かつたりして いるため，管理圆から巽常の原因分分つても，との異常 を将来る繰返すことになる場合がある。

從つて製銅作業では，この上5各種の装因について 解析を行つて、いるいるな關俰を定量的に把握して行く ことが必要心゙すると思 5.

「管理圆は修正戱置が十分とれなりれば止するき か.」というと，そ5は考えない，管理圖注品質水準の 保持, 姴因心船析にかなり役立つ。

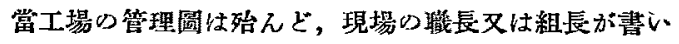
ているので，管理圖を菁くことにより，自分の責任笨图
の作業について，そ凤實體を把握することができる、文

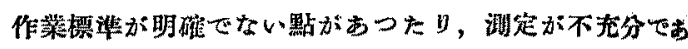

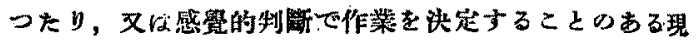

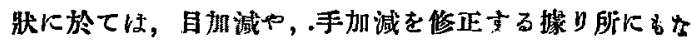
วている.

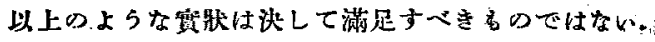
とのためには作策標溜をより明碓なるのにすることが，

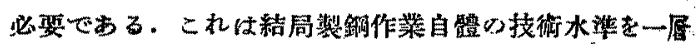

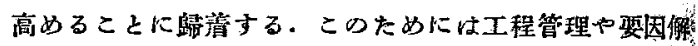
析の目的に適合するサンブリング，测定法などについた

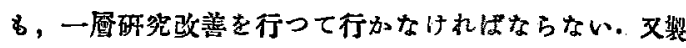
銅作業の各種要因の獬析のため，各種の繖計的手法も充 分活用して行かなりればならない，更に管理圆は檢定， 解析心結果を極力萢用して，管理項目老結果的，綜合 的なるのからこれらの姴因となるものに改めて行く必 要がある.

\section{VI. 結 言}

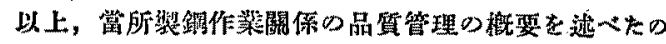
であるが，賽施以來 1 年牛，品質管理心初期的段階心職 貝, 工貝心教育は一通り釉り，管理圖心膲用，普及，赫 計的檢定法，解析法心利用等は日常行われている。そし て前述の如き效果る舉つている。

然し，李だ管理圆は旮分に活用され，又その機能を无

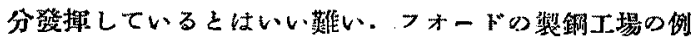
などから推して見ても，これは肯づけることで，現在は はだ,アナライジングの時期と侤えられる。

今後子管理圆, 統計的手法を驅使して, 諸種の變動要 因を定㝵的に和元，調整できるようにして行くことが必

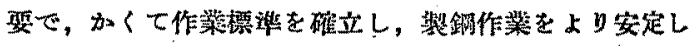

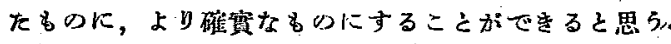

(昭 27 - 12 月寄稿) 